\title{
Paving the Way for New Literacies Integration in Elementary Teacher Education
}

\author{
Laurie Friedrich, Guy Trainin \\ Teaching, Learning and Teacher Education, University of Nebraska-Lincoln, Lincoln, USA \\ Email: gtrainin2@unl.edu
}

Received 14 May 2016; accepted 9 July 2016; published 12 July 2016

Copyright (C) 2016 by authors and Scientific Research Publishing Inc.

This work is licensed under the Creative Commons Attribution International License (CC BY).

http://creativecommons.org/licenses/by/4.0/

(c) () Dpen Access

\section{Abstract}

This collective case study examines new literacies integration by student teacher/cooperating teacher dyads supported by a coach in elementary schools. The theoretical lens for this study combines two areas: the TPACK framework for examining technology integration into teaching and a transformative "Third Space" approach to growing practitioner knowledge. The study took place in a large Midwestern public school district where many student teachers from a public university complete their student teaching experience. The research explored how collaboration in new literacies integration was enacted between student teacher, cooperating teacher, and coach. Results are organized around three themes: collaborative approaches to integration, affordance and effort, and expectations with support. Examination of the enactment of new literacies integration led us to create an innovative teacher education model. In the proposed Triarchic Model of Teacher Education, a university coach supports the concurrent development of preservice and inservice teachers in technology integration.

\section{Keywords}

Teacher Education, New Literacies, Technology Integration, Collaboration, Coaching, Professional Development

\section{Introduction}

To be global citizens, students must develop $21^{\text {st }}$ century skills to effectively use technologies needed in today's world (IRA, 2009; Partnership for $21^{\text {st }}$ Century Skills, 2009). More and more the “digital divide” refers to the ability to effectively locate, integrate, evaluate and create useful information for a variety of purposes (Digital 
Transformation, 2007). These emerging processes require new digital ways of learning, planning, and teaching. For teachers to integrate $21^{\text {st }}$ century skills into the curriculum, they must receive ongoing professional development. At the same time, teacher educators must prepare preservice teachers to plan and facilitate learning experiences integrated with meaningful new literacies. This study examined a collaborative process that combines student teachers, cooperating teachers, and a university-based coach when attempting to integrate new literacies.

\section{Need for New Literacies}

Students today are expected to use print and digital sources to research topics and communicate learning multimodally (e.g. CCSS-ELA: National Governors Association, 2010; NCTE, 2008). New technologies are emerging almost daily, each requiring literacy skills and strategies to fully utilize their potential (Leu, 2010). In this study the authors use Leu and colleagues' definition of new literacies:

The new literacies of the Internet and other ICTs include the skills, strategies, and dispositions necessary to successfully use and adapt to the rapidly changing information and communication technologies and contexts that continuously emerge in our world and influence all areas of our personal and professional lives (Leu, Kinzer, Coiro, \& Cammack, 2004: p. 1572).

As students' use of technology outside and inside schools continues to grow, teacher education has to adapt to these new needs. What is needed are teachers who can leverage new literacies to transform learning.

\section{Literature Review}

\subsection{Change in Pedagogical Practices}

Pedagogy, the art and science of teaching, transforms in the digital age to an emphasis on the act of learning (Beetham \& Sharpe, 2013) as students oscillate between consuming and creating. Teachers have always needed to be life-long learners, but in the face of changing technology the need is even greater. In this time of transition not all teachers are ready to effectively integrate technology for teaching and learning in meaningful ways (Li, 2007; Bauer \& Kenton, 2005; Stolle, 2008).

Research has shown that teachers and student teachers are more likely to use technology as a supportive instructional tool than to empower students to ask questions and find their own answers using new literacies (e.g. Choy, Wong, \& Gao, 2009-2010; Palak \& Walls, 2009). To prepare teachers to teach new literacies in these student-centered ways, educational systems need effective forms of professional development and teacher education.

\subsection{Teacher Professional Development}

Teachers have always needed ongoing professional development to remain current with research-based best practices. Guskey's (1995) results-oriented professional development study notes that for teachers to make changes in their teaching practices they need opportunities to apply new skills personally, to practice the new strategy with students, and to collect student data to justify conclusions. Professional growth coupled with positive student outcomes motivates teachers, which in turn may cause a change in their practices. Guskey (2003) reviewed lists of criteria for effective professional development and found the following to be most helpful: 1) enhancement of teachers' content and pedagogical knowledge focusing on subject matter and how students learn that material, 2) sufficient time and resources that are well-organized and purposeful, and 3) collegiality and collaboration for working together, reflecting on methods, exchanging ideas, and sharing strategies with goals to increase student learning.

When applying these tenets of professional development to new literacies integration, Borko, Whitcomb, and Liston (2009) point out the "wicked problem" that challenges teachers when trying to add rapidly-changing technology to existing content and pedagogy knowledge. Professional development must now add technology knowledge to the content and pedagogical knowledge which Guskey (2003) suggests, building upon the Technological Pedagogical Content Knowledge (TPACK) model as described by Koehler and Mishra (2008). Integrating new literacies can confuse teachers when trying to select appropriate technology to meet content standards using a variety of teaching methods even as technologies are rapidly evolving. In addition, teachers are called to change roles to allow the student to be the investigator while the teacher serves more as a coach, in this transformative type of teaching often requiring a paradigm shift. 
Insufficient Professional Development for New Literacies

The literature shows that the one-workshop approach to professional development has not helped teachers integrate technology into the required curriculum (Cuban, Kirkpatrick, \& Peck, 2001; Hutchison, 2012). On the whole, less than ten percent of teachers implement strategies learned in traditional workshops into their actual teaching (Joyce \& Showers, 1988). Often there is a lack of ongoing support and collaboration for teachers following professional development (Brinkerhoff, 2006; Hutchison, 2012). Joyce \& Showers (2002) show that when ongoing peer coaching is provided following the workshop, ninety-five percent of participants transferred learning to classroom practice. Building upon the proven value of ongoing coaching the authors consider effective practices for new literacies professional development.

\subsection{Best Practices for Teachers Learning Technology}

Applying effective professional development strategies to technology integration helps teachers learn in ways that respect their current teaching. Trusted mentors and peers provide support to meet specific curriculum needs while collaborating to compose meaningful lessons (McKenzie, 1999). Integrating professional development into classroom teaching, teachers change their practice in context. As new practices are scaffolded and supported teachers gain confidence in new literacies. For desired changes in new literacies integration to occur, teachers need opportunities to experiment with new ideas in their classroom and examine student outcomes (Guskey, 2002).

\subsubsection{Coaching}

Instructional coaches are an example of mentors supporting teachers in their daily work (Dole, 2004). Coaches provide onsite professional development as they demonstrate evidence-based practices and support teachers during planning and enactment of new pedagogy. The coaching process entails motivating, modeling, observing, and providing feedback (Lyons \& Pinnell, 2001). Research shows that coaching can be effective in traditional literacy instruction (e.g. Taylor, Pearson, Peterson, \& Rodriguez, 2005; Matsumura, Garnier, \& Resnick, 2010). However, there have been relatively few studies of new literacies coaching (Grove, Strudler, \& Odell, 2004).

\subsubsection{School/University Partnerships}

Wright and Wilson (2005) suggest that for change to take place in technology integration, preservice teachers must be effectively prepared to be part of the change process. Few preservice teachers, however, observe and participate in new literacies integration in methods courses or field experiences (Ertmer \& Ottenbreit-Leftwich, 2010). Ertmer \& Ottenbreit-Leftwich propose specific roles for preservice teachers, and suggest that inservice teachers should provide modeling. The challenge is that inservice teachers are often not prepared to guide new literacies integration. This is exactly where teacher education programs in universities can serve both preservice and inservice teachers.

\section{Theoretical Perspectives}

Our theoretical lens combines two areas: a framework for examining technology integration into teaching and an approach to growing practitioner knowledge. The authors situated this study in the Technological Pedagogical Content Knowledge (TPACK) framework (Mishra \& Koehler, 2006) (see Figure 1). Building on Shulman's (1987) concept of Pedagogical Content Knowledge, Mishra and Koehler (2006) created TPACK as the space where important learning happens at the intersection of teacher Content Knowledge, Pedagogical Knowledge, and Technological Knowledge. This study examines the process of merging teacher Technological Knowledge into Pedagogical Content Knowledge as elementary teachers and their student teachers integrate new literacies into teaching and learning.

Addressing practitioner knowledge and the challenges of teacher education, Gutierrez (2008) calls for a "Third Space" where practitioner knowledge in schools is merged with academic knowledge in universities in new ways to enhance preservice teachers' learning. This transformative space can be less hierarchical so knowledge from cooperating teachers, university methods instructors, and supervisors/coaches is equally valued as providing expanded learning for everyone involved. Similarly, Zeichner (2010) calls for a more conversational relationship between equals as cooperating teachers and professors learn with preservice teachers. In this study the university supervisor used a coaching model to create a space in which both cooperating teacher and student 


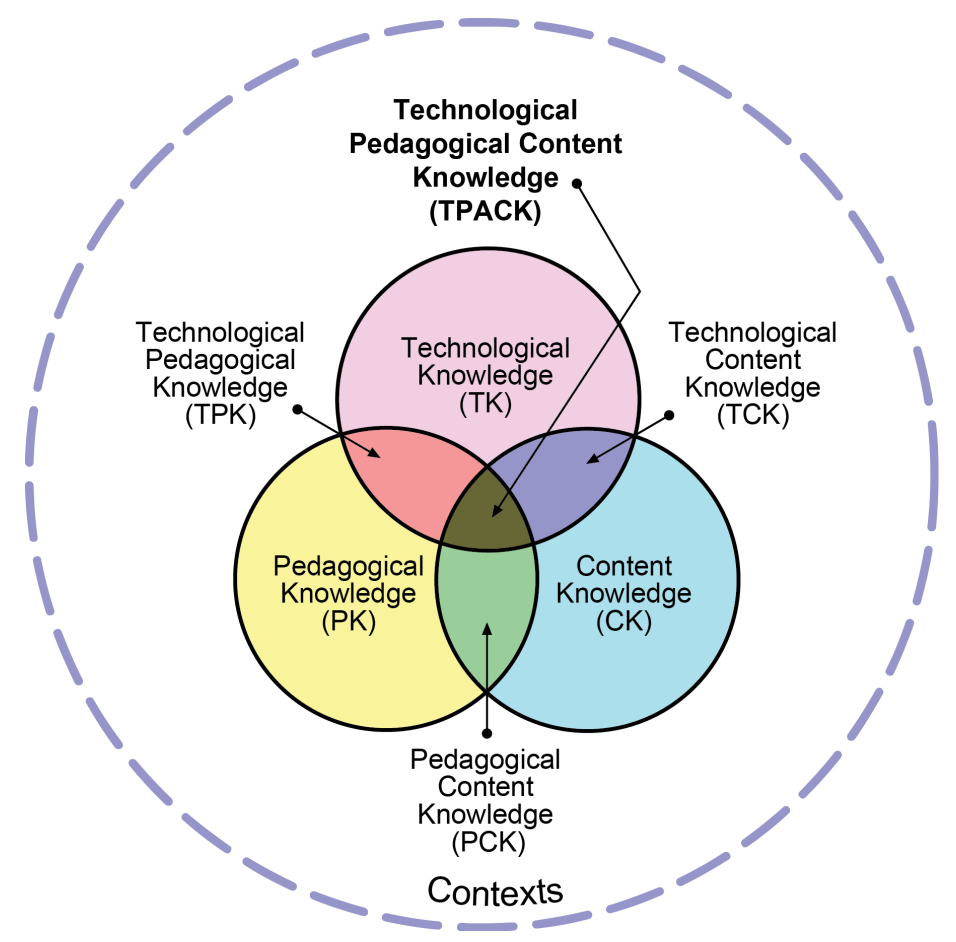

Figure 1. Technological Pedagogical Content Knowledge creates learning at the center of TPACK where students use technology to learn in ways not possible without its affordances. Reproduced by permission of the publisher, (c) 2012 by tpack.org http://tpack.org.

teacher integrate new literacies, an area where each partner can contribute teacher knowledge of content, pedagogy, and technology (see Figure 2).

\section{Purpose of the Study and Research Question}

The primary aim of this study was to examine new literacies integration by student teacher, cooperating teacher and university-based coach in elementary schools. A secondary goal of this study was to determine how these teachers integrated content, pedagogy, and technology through the lens of TPACK (Mishra \& Koehler, 2006). The main research question addressed by this case study was: How is collaboration in new literacies integration enacted between a student teacher, a cooperating teacher, and a coach?

\section{Methods}

The authors employed a collective case study design (Stake, 1995) with five dyads and a coach to develop a picture of what new literacies integration looks like in elementary classrooms that took advantage of this support model. The authors wanted to discover through interaction with both student teachers and cooperating teachers individually, as well as by dyads, what their experience of new literacies integration was like during student teaching. Each case was explored individually with multiple sources of evidence triangulated during interpretation to reveal patterns, then comparisons between cases were made (Stake, 2000). The researchers will refer to cooperating teachers as CTs and student teachers as STs.

\subsection{Context}

The study (Fall 2014 semester) took place in a large Midwestern public school district where many student teachers from a large Midwestern public university completed their student teaching experience. The five cooperating teachers taught at four different elementary schools in this district, with two teachers located in the same school (see Table 1). 


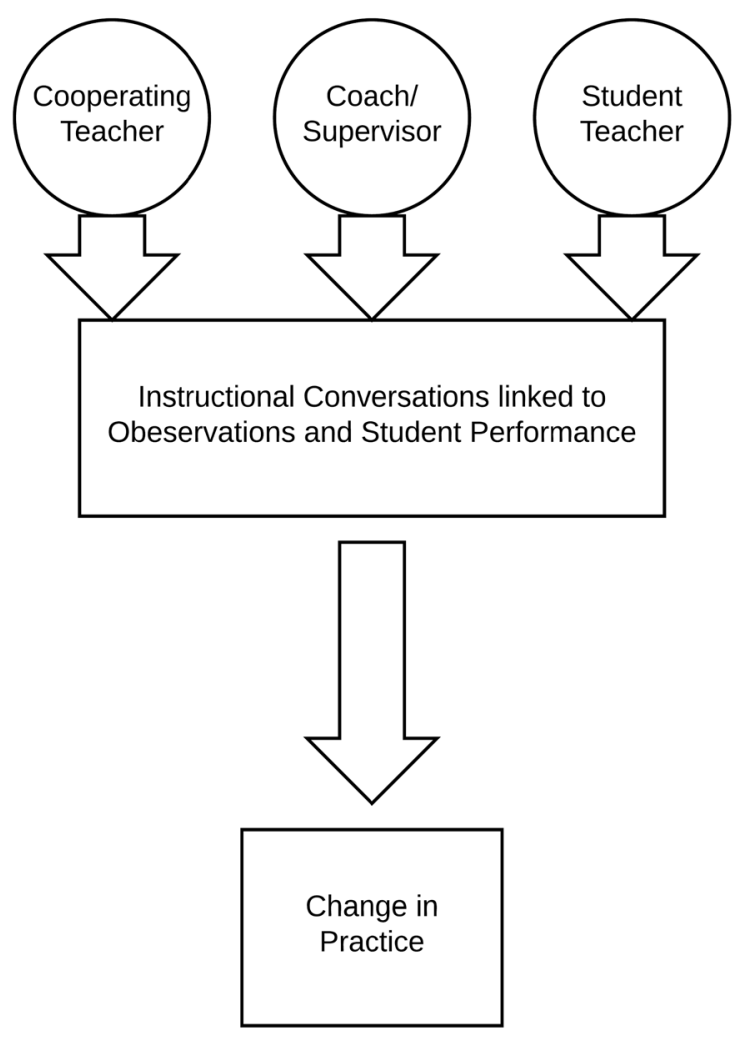

Figure 2.The third space.

Table 1. School demographics and classroom size.

\begin{tabular}{cccccccccc}
\hline School & Title I & $\begin{array}{c}\text { \#Students } \\
\text { in School }\end{array}$ & \% Free/Reduced Lunch & $\begin{array}{c}\% \\
\text { Minority }\end{array}$ & $\begin{array}{c}\text { \% Special } \\
\text { Education }\end{array}$ & Dyad & Grade & \#In Class \\
\hline Bakewell & Yes & 258 & $86 \%$ & $45 \%$ & $28 \%$ & Mr. Wichert \& Mikayla & 4 & 15 \\
& & & & & & Ms. Langston \& Lauren & 3 & 17 \\
Carson & No & 487 & $22 \%$ & $12 \%$ & $20 \%$ & Ms. Majeres \& Sarah & 2 & 20 \\
Fenton & No & 500 & $22 \%$ & $15 \%$ & $15 \%$ & Ms. Stout \& William & 2 & 24 \\
Arlington & Yes & 763 & $67 \%$ & $34 \%$ & $16 \%$ & Ms. Lisko \& Angeline & K & 22 \\
\hline
\end{tabular}

\section{Description of the Schools}

School 1. Bakewell Elementary (all school, cooperating teacher, and student teacher names are pseudonyms), a Title I school with 86 percent of students qualifying for free or reduced lunch, was the smallest of the schools represented in the study. Forty-five percent of the students were classified as minority, and 28 percent qualified for special education services. Two cooperating teacher/student teacher dyads were located at Bakewell during the study.

School 2. Carson Elementary was a medium-sized school in this study with 22 percent of its students qualifying for free or reduced lunch. The school was located in a neighborhood where many professional people live and send their children to the school. It had the lowest percentage of minority students of the participating schools. One cooperating teacher and her student teacher in the study were located at Carson this semester.

School 3. Fenton Elementary is a middle-sized school most similar to Carson Elementary in size with the same 22 percent of students qualifying for free or reduced lunch. The percent of minority students was a bit higher at 15 percent, and the number of students qualifying for special education was a bit lower at 15 percent. One dyad in the study was located at Fenton.

School 4. Arlington Elementary is a newly designated Title I school. It is the largest school in the study with over 750 students, 67 percent of whom qualified for free or reduced lunch. With 34 percent minority students 
and 16 percent of students qualifying for special education, teachers at Arlington are quickly transitioning to a changing student population. This school is located the furthest from the city center. One dyad at the kindergarten level from this school participated in the study.

\subsection{Participants}

The researchers used criterion purposive sampling (Miles \& Huberman, 1994) to select student teacher/cooperating teacher dyads, where student teacher and associated cooperating teacher both indicated an interest in participating in further collaboration to integrate technology. Five CTs and five STs taught at four different elementary schools in this district, representing a continuum of learning environments and challenges.

\subsubsection{Cooperating Teacher Participants}

Teacher demographics closely represented elementary teachers in the region where this study took place. The group of cooperating teachers was mainly female with one male, and largely Caucasian with one AfricanAmerican. Their teaching experience ranged from six to twenty-seven years, representing a total of sixty-six years of combined teaching experience with an average of 13.2 years. Four of the cooperating teachers had earned masters degrees, one had a bachelors degree; two held additional math specialist certificates.

\subsubsection{Student Teacher Participants}

Student teacher demographics of the five students volunteering to participate in the study also reflected the student population in the elementary education program at this university. The student teachers were largely female, with one male, and all Caucasian. There were three undergraduate and two graduate students in the study ranging in age from 22 to 34 . None of the student teachers had any formal teaching experience beyond practicum experiences in methods courses for the undergraduates, and no experience for the two Masters students who had been prepared for related but different careers as undergraduates.

The names of all participants and schools have been altered to protect their identities. These volunteer teachers were selected from classrooms where both CT and ST volunteered to participate. The authors introduced participants using information gained during beginning interviews. The authors purposefully describe the participants in some detail to show that they represent a varied group in respect to teaching and technology biographies.

Dyad 1. Mr. Wichert was a fourth grade teacher, in his sixth year of teaching, piloting the district's new reading series. He taught at Bakewell Elementary, a diverse Title I school. Mr. Wichert enjoyed learning about new literacies integration and was innovative with a sense of immediacy. He viewed himself as a "facilitator of cognition, not a teacher, helping students focus on their metacognition to learn by understanding what is going on in their minds" (Mr. Wichert, Beginning Interview). Mr. Wichert rated his technology ability personally and for teaching as 4 on a scale of 1 - 5 where 1 is low (novice) and 5 is high (expert), and he rated his interest in using technology as 5 using the same scale (all CTs and STs self-evaluated using the same scale).

Mikayla student taught with Mr. Wichert for the year. She graduated with a bachelor's degree in Family and Consumer Sciences with Child Development Studies several years before. She had no teaching experience prior to entering the program. Mikayla entered the Masters teacher certification program to help children learn and succeed. She spent two full days in the classroom throughout the semester and believed students learn through hands-on activities, asking questions and finding information on their own. Mikayla ranked herself as just above novice in her ability to use technology personally and professionally, and for interest in using technology in teaching.

Dyad 1 was the most diverse in perceived technology ability and interest, with Mr. Wichert highly competent with high interest in using technology in teaching and Mikayla feeling less competent and with lower interest in technology use.

Dyad 2. Ms. Langston, an African American teacher, taught third grade at Bakewell. She brought 25 years of teaching experience to this Dyad, from other states as well as different school districts within the state. "I just feel like I can relate, coming from my background to the Title I situation, and I want to just pay it back. You know, people invested in me and so I want to do the same thing for my students” (Ms. Langston, Beginning Interview). Ms. Langston suggested her greatest strengths were creativity in teaching and building relationships with students, giving them input as they learned together through play that exposed students' creative side. Ms. 
Langston rated her personal and teaching use of technology as 3 competent and her interest in technology for teaching as 4.

Lauren, a Masters student feeling overwhelmed by the demands of both coursework and teaching, was Ms. Langston's ST. She earned a bachelor's degree in Marriage and Family Therapy and wanted to use this expertise as a classroom teacher. She listed her greatest strengths as empathy, listening, and caring. Building upon her background working with children and adolescents with emotional and behavioral problems, she viewed students as learning best “when they feel supported and they feel they can do it...which unfortunately doesn't happen a lot” (Lauren, Beginning Interview). Lauren rated herself 4 in personal technology ability, but 1 novice in technology ability for teaching. She indicated a moderate interest in technology for teaching.

Dyad 2 presented an interesting mix of self-perceived technology ability and interest. Lauren used technology personally at a near expert level, but because of her lack of teaching experience she rated herself novice in ability to integrate technology into her teaching. Her CT Ms. Langston rated herself lower than Lauren in ability to use technology personally but higher in ability to use technology in teaching and interest in using technology in teaching.

Dyad 3. Ms. Majeres taught second grade at Carson Elementary, serving students mostly from middle class backgrounds. Despite eight years of teaching experience, this was the first year she had an LCD projector and document camera in her classroom. Her previous school did not have much technology and no computer teacher, so she was not used to using technology in instruction. Ms. Majeres was not sure about what technology was available to her at Carson.

We have a computer lab that's available in the mornings, but we are a non-testing grade so we are way low down on the totem pole for access to that... And I don't get to use it... And so I don't think about whole class computer usage... I think small group or single kid at a time computer usage. (Ms. Majeres, Beginning Interview)

She described her strengths as managing the class and working with struggling readers by scaffolding lessons from simple to complex. She believed students need multiple opportunities using multiple modalities to learn best; they need to see it, say it, and write it so it sticks in their brain. Ms. Majeres rated herself 4 in her ability to use technology personally, 3 competent in ability to use technology in teaching, and 5 high interest in learning to use technology.

Sarah was an undergraduate student who taught with Ms. Majeres and admired her as a teacher, selecting her as CT after completing a practicum with her the year before. Sarah described her almost nonexistent technology background, homeschooled where her Mom limited TV to thirty minutes per day and no exposure to video games. Sarah did not indicate much interest in technology rating herself as 3. In terms of her ability to use technology in teaching, she rated herself 2 just above novice. Sarah explained that she found it difficult to try new things with technology and hard to motivate herself to try. "I feel like whenever I try to use technology it doesn't work for me, I don't know if I'm just prone to not [be successful using technology], and I'm sure that's just something that's gotten into my head (Sarah, Beginning Interview).

In Dyad 3, both Ms. Majeres and Sarah talked about needing accountability to actually use technology, not just think of a good idea but actually try it in teaching. While Ms. Majeres rated herself higher than Sarah in all areas, both CT and ST were unsure of themselves using technology.

Dyad 4. Ms. Stout was a second grade teacher at Fenton Elementary, serving students from mostly middle class families. She was a seventeen-year veteran of special and elementary education. Ms. Stout described herself as loving children, enjoying coming to school everyday, and challenging herself to keep growing for the children. She wanted to learn to use the tablet for teaching and learning, "Because I never even picked one up until I went to the technology conference!” (Ms. Stout, Beginning Interview). While she rated her ability to use technology personally and professionally at 3 competent, she rated her interest in using technology 5 high.

Knowing that the kids come in already knowing so much, I need to be up there with them. I feel like I need to know more about it, how to use it. And the main thing is I don't want to use it as a bribe or as a "Oh, if you do good you can use this." I want to use it as, "This is how we integrate it all the time.” (Ms. Stout, Beginning Interview)

Ms. Stout's undergraduate ST, William described himself as “a hands-on teacher who likes to see his students interacting with each other and the teacher to learn in creative ways so they can retain information” (William, Beginning Interview). His stated strengths included adapting material for students who did not understand a concept and improving instruction to challenge students on-the-spot, because he had difficulty with time management when teaching. William rated his personal and professional technology skills as almost expert, and his 
interest in using technology for teaching at the highest level of 5 .

William and Ms. Stout attended a technology conference together and both attended the session on e-book creation. In Dyad 4 William was more confident in his use of technology but both ST and CT indicated the highest level of interest in learning to use technology in teaching.

Dyad 5. Ms. Lisko was a kindergarten teacher at Arlington Elementary, a diverse Title I school and the largest school in the study. She had eight years of teaching experience and expressed confidence in her personal technology skills. Confidence, flexibility, and technology were her stated strengths along with approachability and a positive attitude. Ms. Lisko described herself this way, "I'm a fly by the seat of my pants person. I'll do whatever. I'll just try it and if it doesn't work we'll try something different. Whatever you want us to try we'll try” (Ms. Lisko, Beginning Interview). While she rated herself 4 near expert in personal technology ability, she rated herself as 3 competent at using technology in teaching. Ms. Lisko knew that there was a laptop cart in the school and said she would love to use these computers in her classroom, but she just didn't know what to do with them. She believed students learn by doing in hands-on fashion, focusing on their strengths and accommodating as needed. She shared that this was how she learns as well, "I have to do it myself!" Regarding her interest in using technology in teaching, she rated herself highest at 5.

During the semester of the study Ms. Lisko worked with Angeline as her ST. Angeline was an undergraduate student teacher who led a sectional on creating e-books at the technology conference they attended together, something she learned to do during the university reading clinic course. Like Ms. Lisko, she rated herself as 3 competent at using technology in teaching, and 5 high regarding her interest in using technology in teaching, only their self-rating of personal use of technology differed where Angeline rated herself 3 competent, one lower than Ms. Lisko rated herself. Angeline stated that her greatest strengths were organization, communication, and collaboration. She believed real learning happens when students are involved in hands-on productive activities that engage as many students as possible.

Overall the members of Dyad 5 viewed themselves as very similar in technology ability. However, their preferred method of integrating technology differed: whereas Ms. Lisko was a "try it" user ready to try anything, Angeline was a "plan it" user preferring to collaborate and plan lessons together.

\subsection{Professional Development Context}

Coach. The coach was an experienced technology coach at the end of her doctoral program focusing on new literacies studies. She applied her previous experience teaching at the elementary level to her work in the teacher education program. Previously, the coach assisted with a tablet initiative at the university reading clinic, guiding undergraduate preservice and graduate inservice teachers to effectively use technology with struggling readers. While she had more experience using tablets to teach, the coach considered herself a learner who continued to seek out new apps and teaching uses to share with these pre-and inservice teachers.

The technology conference. Each of the CT participants was invited to attend a technology conference at the university with his or her ST at the beginning of the student teaching semester; all but the two graduate STs attended because of conflicting class requirements. The conference had over 250 participants and offered multiple sectionals on new literacies integration in elementary schools presented by elementary teachers and education specialists in a hands-on format, allowing participants to practice using the technologies in a supportive environment.

Workshop. The authors provided a half-day workshop for all participants to meet each other and receive focused professional development. The schedule included creating e-books and graphs, troubleshooting technology questions, providing apps as requested, planning for continued collaboration, discussing new literacies, and clarifying coaching parameters. The highlight of the workshop was having each dyad share a way they were integrating new literacies into the classroom. Hearing what other teachers were doing motivated everyone, and in the weeks to come, participants tried several of these ideas in their classrooms.

\subsection{Coaching Procedures}

The coach explicitly spent nine weeks of the study in the field with participants as coach building relationships and mentoring in new literacies integration. As a technology integration coach, the coach became a support person for the dyads collaborating to integrate new literacies in the classroom. To accomplish these goals the coach 
followed Vogt and Shearer's (2011) Mixed Model of Coaching, incorporating both formal and informal methods. the coach supported practice and created expectations necessary for successful implementation of professional development (Guskey, 2002; Kelley, Gray, Reid, \& Craig, 2010). The coach incorporated Guskey's Characteristics of Effective Professional Development (2003) into her coaching including: follow-up, support, and pressure; enhancing teacher content knowledge and pedagogical knowledge; promoting collegiality and collaboration; meeting on-site; and stressing student learning outcomes.

Formal coaching procedures included: assisting in goal setting, co-planning lessons, and leading professional development. The coach held participants accountable for integrating new literacies by having them complete weekly Logs and participate in weekly meetings.

Informally, the coach functioned as a knowledgeable co-learner, sharing apps and teaching ideas while also learning. The coach was able to work alongside the dyads and experience the process of new literacies integration with them. She created an online community to support all dyads, to share ideas, and to ask questions as a way to extend the collaboration. The coach gave one tablet for each classroom, except the two dyads at Bakewell who shared one tablet.

The coaching session. Weekly coaching meetings followed a standard format individualized to meet the needs of each participant. Each CT and ST individually completed a weekly online Technology Use Log. Informed by logs, the coach prepared an agenda for each dyad's separate weekly coaching session. The coach introduced specified apps to all dyads then the coach personalized the sessions to assist individual participants in meeting goals. Each session included: 1) relationship building, 2) overviewing new literacies integration from the previous week, 3) discussing the importance of new literacies for students, 4) encouraging dyads in their collaboration for integration, 5) reviewing ideas shared in last week's coaching session to allow for questions or examples of use, and 6) demonstrating new apps and websites with specific teaching ideas to meet dyad needs. This provided continued follow-up, support, and accountability. Following each coaching session the coach documented procedures in coaching notes $(\mathrm{n}=38)$.

\subsection{Data Sources}

Email. The authors collected all email exchanges $(n=197)$ throughout the semester for analysis. Most of the messages were questions or requests for assistance.

Online community posts. To encourage ongoing collaboration across dyads, the authors created a social networking site. The authors set up a small group for each dyad, and a large group for all participants together. This site served as a message board for communication and collaboration throughout the semester. It was used to share websites, teaching videos, lists of recommended apps, and examples of student projects $(n=52)$.

Interviews. The authors conducted 30-minute semi-structured interviews at the beginning and end of the study with each ST and CT separately. The authors used the Beginning Interview Protocol (see Appendix A) to learn about each participant as the study began focusing on strengths, goals, experiences using technology, and possible questions about the study. At the conclusion of the study the authors used the Exit Interview Protocol (see Appendix B) to explore each participant's perception of the student teaching semester focusing on the experience of new literacies integration including collaboration, ST/CT roles, coaching, best student projects, perceived impact of new literacies focus, and further goals.

Each dyad additionally participated in a final interview together at the end of the semester (see Appendix C). Questions tapped into: 1) what was most helpful about having a partner while integrating new literacies, 2) what helped students learn the most, 3) what technologies were most helpful in teaching, 4) how the added focus on technology affected them as a ST/CT dyad, and 5) what suggestions they would give to incoming ST/CT dyads to make their new literacies integration most beneficial for teacher and students. This dyad interview format provided insights into how each dyad worked together through their responses verbally as well as nonverbally.

Observations. Four one-hour classroom observations with associated field notes were conducted with each dyad using the Observation Protocol (see Appendix D) in the classroom or computer lab while they were teaching a lesson integrating new literacies $(n=20)$. The protocol focused the observation on: 1$)$ the objectives for content and technology, 2) teacher pedagogy, 3) student use of new literacies, 4) relevant quotes, and 5) unexpected events. 
Teacher technology logs. The CTs and STs individually completed the Teacher Technology Log (see Appendix E), a self-reporting online tool to gather information about dyads' use of technology, collaboration, areas of learning, and goals $(\mathrm{n}=68)$. The logs were based on existing models of teacher logs in the literature (e.g. Ball, Camburn, Correnti, Philps, \& Wallace, 1998). The log captured: 1) frequency of technology lessons, 2) technology integration time, 3) subjects, 4) collaboration, 5) best technology uses, 6) goals, and 7) requested coaching assistance.

Data Analysis. The authors transcribed audio-recordings of interviews then organized all data sources ( $\mathrm{n}=$ 400) by dyad. To explore the data the authors used the Miles and Huberman (1994) method of coding. First, the authors read through all data to get a sense of the content and create codes. Next, the authors reread all data using open coding assigning codes to text quotations. They reread a third time analytically looking for patterns and answers to research questions. After combining codes into themes, the authors used a selective coding process to look for quotes and examples from participants to illustrate each theme, as well as contradictory evidence to inform themes. Rich and thick quotes (Creswell, 1998) were selected to give voice to the participants as they explained new literacies integration from their point of view. Sorting by codes, the authors examined data first by individual dyad case and then across cases.

Validity. The authors collected multiple sources of evidence from each dyad to accurately and completely describe the phenomenon of new literacies integration as experienced by these participants. Triangulation of these data sources provided corroborating evidence to inform each theme (Miles \& Huberman, 1994). The authors used member checking, taking summaries of themes back to dyads asking them to indicate if the themes accurately reflected their experiences (Creswell \& Plano Clark, 2011).

Reliability. Inter-coder agreement was examined following the procedure suggested in Creswell (2013). An independent coder coded representative samples from the data using a codebook. The Inter-coder agreement for this study was $84 \%$ which exceeded the criteria recommended by Miles and Huberman (1994).

\section{Findings}

Although CTs and STs varied in teaching and technology experience, age, gender, school situation, grade, and earned degree, all grew in new literacies integration during this study. The CTs demonstrated high levels of pedagogical content knowledge, however, they were all still learning how to effectively integrate new literacies into their practice.

An examination of the individual cases led to the following themes: 1) Collaborative Approaches to Integration, 2) Affordance and Effort, and 3) Expectations with Support.

\subsection{Theme 1: Collaborative Approaches to Integration}

The authors found that when teachers collaborated they were more likely to invest time and effort into preparing and teaching using new literacies skills learned in professional development. Weekly logs collected data recounting with whom and how each participant collaborated. Coding showed instances of collaboration recorded across dyads organized by patterns: collaboration-general (72), collaboration-dyad (115), collaboration-school team (87), collaboration-planning (57), collaboration-coach (53), collaboration-none (21). In addition, dyads recorded 38 instances of the collaborative term "bouncing ideas" as a way of planning and learning from each other. STs valued input from more experienced CTs as they planned and reflected together:

Be there for each other to bounce ideas off each other and then like you know she's the more veteran teacher so it's nice to be able to bounce my idea off of her and say, "Would this work or not?" and a lot of times she goes "It would work, but maybe just tweak it here or there." So it's nice that I have somebody there that I can talk to and know if it would be a good idea or a bad idea, and if it's a bad idea how we can make it better. (Angeline, Beginning Interview)

CTs also talked about valuing learning from STs:

So she's going to learn some good apps to use or different ways of, you know. Or what she's learning in her classroom, how to bring that in here; and anytime you can get those good, new ideas. (Mr. Wichert, Beginning Interview)

Increased collaborative time. When dyads wanted to try something they saw at the conference or workshop but it was more difficult than the CT or ST felt they could accomplish alone, they frequently reported collabo- 
rating to figure it out and devise a plan. Part of the study required each dyad to lead children in creating a technology project. This expectation challenged all dyads and led to increased planning, teaching, and collaborating.

Each dyad experienced a transitional week when they transformed their teaching to make children creators, beginning in Weeks 6 (Dyad 2) and 7 (Dyads 1, 3, 5) with Dyad 4 celebrating their student-centered shift in Week 10. All CTs reported increased time spent teaching and planning during this transitional week; planning time was more than double the average during the duration of the study, with a $60 \%$ increase in time spent teaching with technology.

Growing collaborative network. Usually dyads collaborated with their dyad partner, but they expanded their collaboration networks during transitional times. Dyad 4 created the largest collaboration network including global collaboration, business collaborations, and professional collaboration with teachers and administrators in the school. Dyad 4 discussed their collaborative process in the following conversation:

So, [my ST was] just kind of teaching me those little baby steps as to how an iPad works. And then it's been fun to bounce ideas off of each other. And think about, "Hey how could we use this? Or we could use this during this time of the day. Or this might be good with this kid.” So just kind of bouncing ideas off and getting ideas from each other has been really beneficial to me as a teacher. (Ms. Stout, Dyad 4 Exit Interview)

And I agree with Ms. Stout... because again there were a lot of things that she mentioned to me where we could integrate technology where I was like, “Wow, I never thought of that!” (William, Dyad 4 Exit Interview)

This interaction was common as CT/ST dyads collaborated to integrate new literacies into their teaching and student learning through team-teaching, facilitating separate groups, working with the whole class, and assisting individual children.

\subsection{Theme 2: Affordance and Effort}

To bring about change in the study participants used a combination of affordances of available devices and teacher time. Dyads used the available devices to deepen teaching by adding the technology layer and changing student activities. All dyads commented on the lack of available technology in their schools and their desire for one-to-one devices, but each found a way to use the tablet loaned to them and school resources to help students learn.

Affordance increased by resourcefulness. Mr. Wichert and Mikayla creatively tweeted screencasts so children could view tomorrow's lesson and then apply learning the next day in class. Knowing that about forty percent of his students had Internet access at home, Mr. Wichert organized a computer station in the lab before school for students who could not access the Internet at home to view the screencast. Rather than saying that children at his Title I school could not learn via the flipped classroom approach, Mr. Wichert found a way to get them online learning using 21st century techniques.

Ms. Langston, seeing the potential value, brought in enough tablets so each two children had one tablet. " 1 , 2 , 3, 4, 5, 6, 7 iPads. Some are mine, some are the university's, take six back down to preschool. To thank them for letting us borrow their iPads you can read a digital book to a preschool child, and let them turn the pages!” (Ms. Langston, Observation 3).

Ms. Majeres and Sarah mainly used the single tablet with individual struggling readers practicing needed skills. They expanded it to whole class instruction as a teaching device. Later when Sarah completed her solo student teaching she used the tablet with a small group to have them create their own graphic organizers. Finally, to use the tablet with more students, Ms. Majeres wrote a grant to apply for a class tablet.

Effort. In addition to resourcefulness, each dyad put forth effort to learn to use devices with students (Weiner, 2004). Although all CTs and STs volunteered to participate in the study, it was not always easy to integrate new literacies. Lauren bemoaned that there were too many apps to select from and that it took time to experiment with and use them in meaningful learning. Ms. Majeres was concerned about the loss of instructional time when technology does not work. Cooperating teachers each reported an average of 30 hours of planning and teaching with technology while STs reported over 10 hours each. This was in addition to regular planning and happened during uncompensated time; yet teachers did not regret investing this impressive amount of time. It allowed them to feel and act like professionals, leading in ways they had not before. The motivation for the extra effort is in line with the literature: they desired to grow professionally (Clarke, Triggs, \& Nielsen, 2014), and they saw students engaged in learning (Guskey, 2002).

At the beginning I was still learning and not so sure of myself. And once I realized that this was like a gateway to so many different opportunities, I decided to get upon myself to learn as much as I could in the time I 
have with him [ST], and with the iPad and things. And it just took me to another level. (Ms. Stout, Exit Interview)

Sarah also noted positive student response: "I learned that most students are more engaged when technology is used!” (Sarah, Log, 10-26). Sarah recorded learning that students really enjoyed getting to use the tablet for assessment. She involved children in sharing what they knew about the life cycle of a plant as they co-created a graphic organizer on the tablet as a review.

To summarize, this study showed teacher growth and empowerment through the affordances of the available devices and effort. Cooperating teachers noted paradigm shifts as they saw their planning and teaching transform to include the technology component, using the affordances of tablets as learning tools rather than teaching tools. Ms. Majeres summarized the change in her perception of teaching with technology, "You use it to learn, not just learn how to use it!” (Ms. Majeres, Exit Interview).

\subsection{Theme 3: Expectations with Support}

Collaboration between CTs and STs with the support of a coach led to an innovative student teaching model. While participants volunteered individually to participate, there was no way for them to fully comprehend at the time of agreement what that commitment would look like when they were in the midst of it. Dyad 2 expressed feeling overwhelmed in the first few weeks, "It was like first week she [Lauren] cried and I was ready to cry. Second week...I was like, 'What did I commit to?' Every time I filled out those logs I was like, 'What did I get into?’ (Ms. Langston, Dyad 2 Exit Interview). But Ms. Langston led the dyad, learned all about the tablet, built student digital repertoires, allowed children to choose apps, create projects, and share them in front of the whole school. By the end of the study Ms. Langston commented, "When I talked to my peers in the building, I feel like I have been so blessed to have this experience because I felt like I got more out of you as my coach,” (Ms. Langston, Exit Interview). This comment mirrored the finding in Scot (2004) that technology coaches assisted teachers with technology and energized the school through these teachers and their updated pedagogy.

Dyad 3 related responding to the expectations of integrating new literacies. Sarah noted, "I think I feel like I was always so rushed to think about what I could do next and how I could incorporate that technology" (Sarah, Exit Interview). In addition, Ms. Majeres commented that they felt pushed to try something new and held accountable, perhaps more than they expected.

Because you could say, "Here Ms. Majeres, here's an iPad." And I could say, "Thanks, I'll play with that." But when you were saying, "How are you using it?" I should probably find out a way to use it... this whole process has also pushed-Sarah because she was very tech timid. (Ms. Majeres, Exit Interview)

The dyad becomes a triad. This is when the dyad became a triad. The coach's presence was not a neutral presence. This third person on the team served as coach to both CTs and STs by encouraging, teaching, supporting, and holding accountable so participants integrated new apps directly into their teaching without giving up.

Coaching. All STs and CTs related the common theme of the importance of a coach when integrating technology. Coaching was a weekly component in this study; even when CT and ST did not collaborate they did get ideas and support from the coach. "And I guess the most collaboration I probably did was probably with you [coach]. Bouncing ideas off of each other, ways to improve a lesson, that's probably the most collaboration I did was with you [coach]" (Angeline, Exit Interview).

Mikayla noted:

Even when we were taking these seemingly small steps you just provided a lot of encouragement and positive feedback that helped me feel like, "Oh, I really can do this right. Even though I know this is really a baby step she is really encouraging me", and that helped me a lot. Helped me not feel so technologically disabled. And then... you would give us apps and encourage us to try them out." (Mikayla, Exit Interview)

Individualized support. In weekly logs STs and CTs noted how the coach could best support them to meet their goals in the coming week. Some asked for specific technology ideas. "You have supplied me with great ideas for apps to use in the classroom. I do have to present ways to "say no to tobacco," do you know of any fun videos that I can show my students to get a conversation started?” (Angeline, Log, 10-26). Some commented on how they were planning to use what the coach taught them at the prior coaching meeting. "Our meeting last week was very helpful! I hope to use e-books and other apps over the next few weeks. I can’t think of anything 
specific that I need help with as of now (Sarah, Log, 10-19-12). STs appreciated the ongoing communication and support through coaching.

Encouragement. Ms. Lisko related the critical role of the coach saying that she would have participated in this study of new literacies integration even without a ST, but she would not have done it without a coach. "[The] key was just participating in the study group, I was like "oh well I have to do something. You know you're not going to change unless you are almost forced to" (Ms. Lisko, Exit Interview). Teachers are busy, so are student teachers. Without the encouragement of a coach, a ST and CT in the middle of student teaching would not likely begin a new venture on their own. However, with the support and encouragement of a coach these five triads did just that.

Patience. Coaching needs to be done with a teacher's busy schedule in mind. The coach had to remind herself that these volunteers took on a new literacies component in addition to their regular teaching. The coach needed to negotiate a plan for all triad members to be successful.

The first weeks were frustrating because teachers didn't seem to do anything between our weekly meetings. I would show them apps, then expect them to use them during the week. I quickly found out that teachers are very busy and many don't like to do school-related work outside of school time. The teachers who used it [tablet] mostly played with it while their student teacher was teaching. They wanted the apps downloaded for them, then show them how to use the app, and give specific examples of how to use it in teaching. Showing student samples of how each app could be used in teaching was very helpful. (Coaching Journal, 10-8)

It took some time, but eventually change happened. The coach encouraged CTs and STs to try things and acknowledged with excitement each small step they took. Soon they were implementing apps in lessons the same day that I demonstrated them! Coaching demanded a fine balance between patience and accountability.

Teacher differences. The coach met weekly with each dyad and found that different CTs and STs were more or less ready to integrate technology in meaningful ways. Coaching sessions focused on areas in which individual dyads indicated a need. By presenting apps as needed with support, all participants took risks for them and made time to teach new literacies skills.

I am energized by Mr. Wichert's passion for technology use, and the immediacy by which he implements it. Andrea noted that she needed to do a Storybird project with one student but didn't know how she could do it. Mr. Wichert said, "Lets do it with the whole class today, and tomorrow." (Coaching Journal, 10-20)

The coach learned that different teachers progress at different speeds regarding technology integration so she needed to individualize the way she coached them. The coach also realized that the Guskey (2002) principle applied to coaches as she was encouraged when the teachers enacted coaching strategies in enthusiastic ways.

When the coach began observing lessons she could see the effects of additional time devoted to learning and integrating new literacies. Tablets were transitioning from a teaching tool to a learning tool as she observed students researching, creating and presenting digitally.

I was so impressed with Ms. Langston's classroom using technology on my first observation! After the workshop Ms. Langston used technology in 11 classes! She practiced for 4 hours at home to set up her iTunes account and learn apps, practicing with them on her nephew... She taught new literacies skills! (Coaching Journal, 11-8)

Teachers responded to coaching efforts with professionalism. They invested time learning to use the apps and quickly implemented them in the classroom. They empowered students to demonstrate learning using these apps and then share their learning with the class and the school. Teachers became leaders.

The data supports technology coaching comprising a key component of a collaborative student teaching model. In this study, the coach assisted CT and ST in a non-evaluative manner so dyads did not feel pressured to be graded and were free to integrate new literacies in transforming ways (Campbell, 1976). This supports the literature that shows that otherwise STs often choose safe teaching methods when being observed by the supervisor (Cornu \& Ewing, 2008). Coaching supported dyads providing apps and teaching ideas, troubleshooting technology issues, observing and providing feedback, and most importantly by building a trusting relationship with each participant, empowering dyads to do all that they did in this brief twelve-week study.

\section{Discussion}

\subsection{The Triarchic Model of Teacher Education}

The data from this new literacies integration study supports the convergent roles of ST, CT, and Coach in enact- 
ing instructional change. As the authors examined the rich collaborative interactions it became clear that a collaborative triad was in the center of the change process. Cooperating teacher, ST, and Coach formed a partnership via coaching meetings, email, logs, observations, interviews, and conferences. Through a process of dynamic tension, each member brought different aspects of teacher knowledge to the collaborative process. Each lesson was ever-changing as different triad members shared and learned. This interaction is the Triarchic Model of Teacher Education (see Figure 3) and the authors propose it as a model for $21^{\text {st }}$ century teacher education that benefits all participants.

While much professional development focuses on general technology knowledge alone (Borsheim, Merritt, \& Reed, 2008), a technology coach can individualize professional development for teachers much as teachers tailor instruction for their students. Our findings support the idea that a preservice teacher in the classroom can be part of a larger change process that impacts the CT and Coach. This Triarchic Model helps explain how CTs, STs, and Coach integrate new literacies together. Through collaboration it is a shared, expanded Technological Pedagogical Content Knowledge moment as CT, ST, and Coach plan, teach, and reflect together. This back and forth action creates a dynamic tension as each member contributes his/her area(s) of teacher knowledge. The overlap between Technology, Pedagogy, and Content Knowledge grows when all three partners collaborate and contribute their specific strengths.

The triad provided time to explore and plan lessons, helped access and use school technology to practice learning following professional development, and shared ideas for integrating new literacies directly into specific content and standards (Stolle, 2008; Hutchison, 2012). The Triarchic Model of Teacher Education describes how the divergent CT, ST, and Coach converge in a transformative space. This space is less hierarchical so knowledge from all three partners is valued and roles are more flexible (Zeichner, 2010).

\subsection{Study Significance}

The literature shows that traditional professional development has not sufficiently focused on integrating

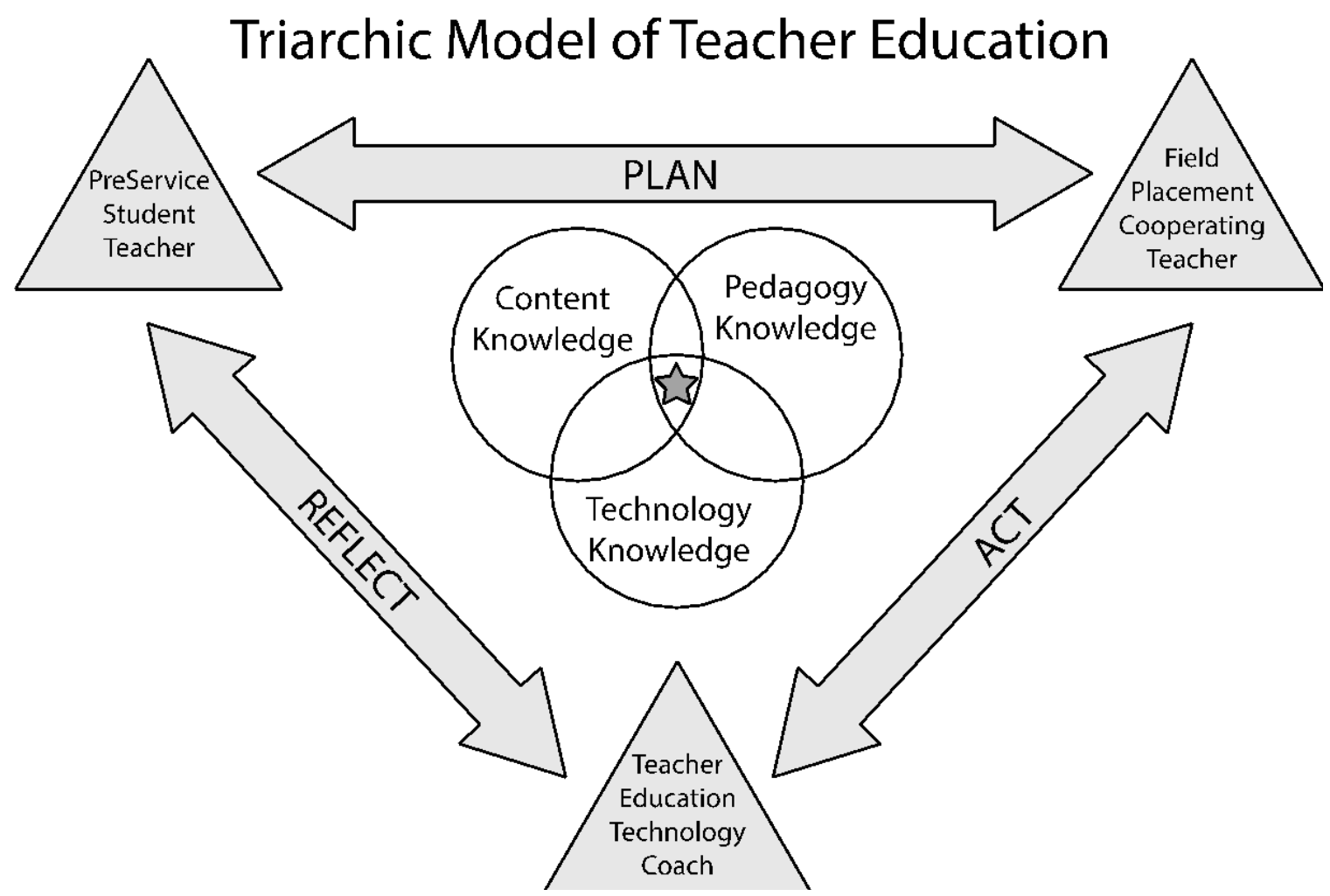

Figure 3. The Triarchic Model of Teacher Education. Creating Technological Pedagogical Content Knowledge via dynamic tension in a transformative space in teacher education where each partner can contribute teacher knowledge of content, pedagogy, and technology. Adapted from (Mishra \& Koehler, 2006, http://tpack.org). 
technology into the curriculum while meeting teachers' needs (Cuban, Kirkpatrick, \& Peck, 2001; Mumtaz, 2000). In addition, teachers indicate a lack of ongoing support and collaboration to integrate technology into instruction following professional development (Brinkerhoff, 2006; Hutchison, 2012; Mouza, 2002, Mumtaz, 2000). The Triarchic Model of Teacher Education answers a call in the literature for a collaborative model of new literacies integration in teacher education (Duran \& Fossum, 2010; Lawless \& Pellegrino, 2007, Choy, Wong, \& Gao, 2009-2010), meeting the stated needs of CTs in addition to STs (Busby \& Mupinga, 2007). This qualitative collective case study went beyond individual CT or ST uses of technology to examine the collaborative processes involved in expanding Technological Pedagogical Content Knowledge for new literacies integration. Learning to work in triads may better prepare preservice teachers for their professional lives. This bond may be extremely helpful preparation for the kind of teamwork that is often expected in schools. At the same time this approach supports practicing teachers as they attempt to transform their instruction.

\subsection{Implications for Future Research}

The Triarchic Model of Teacher Preparation offers a new collaborative design for TPACK integration into innovative lesson design. This model needs to be studied more closely to look for further design suggestions. Do certain characteristics of CTs, STs, and Coaches make them more effective at integrating new literacies together? How does technology ability of CT and ST affect outcomes? Can this model be scaled to be an integral part of the teacher education program? How could the university supervisor role be reimagined when implemented by the coach? And, will online collaborative groups be effective for new literacies integration, per the call from Lawless and Pellegrino (2007)?

\subsection{Limitations}

This study was conducted with five ST/CT dyads and an expert coach. It is not clear how the results of this study would generalize with a less experienced coach, or how scalability is possible.

\section{Grant Recognition}

An Improving Teacher Quality Grant from the Nebraska Post-Secondary Coordinating Commission provided partial funding.

\section{References}

Ball, D. L., Camburn, E., Correnti, R., Philps, G., \& Wallace, R. (1998). New Tools for Research on Instruction and Instructional Policy: A Web-Based Teacher Log. Center for the Study of Teaching and Policy: University of Washington. http://depts.washington.edu/ctpmail/PDFs/Teacher_Log.pdf

Bauer, J., \& Kenton, J. (2005). Toward Technology Integration in the Schools: Why It Isn’t Happening. Journal of Technology and Teacher Education, 13, 519-546.

Beetham, H., \& Sharpe, R. (Eds.) (2013). Rethinking Pedagogy for a Digital Age: Designing for 21st Century Learning. New York: Routledge.

Borko, H., Whitcomb, J., \& Liston, D. (2009). Wicked Problems and Other Thoughts on Issues of Technology and Teacher Learning. Journal of Teacher Education, 60, 3-7. http://dx.doi.org/10.1177/0022487108328488

Borsheim, C., Merritt, K., \& Reed, D. (2008). Beyond Technology for Technology’s Sake: Advancing Multiliteracies in the Twenty-First Century. Clearing House: A Journal of Educational Strategies, Issues and Ideas, 82, 87-90.

http://dx.doi.org/10.3200/TCHS.82.2.87-90

Brinkerhoff, J. (2006). Effects of a Long-Duration, Professional Development Academy on Technology Skills, Computer Self-Efficacy, and Technology Integration Beliefs and Practices. Journal of Research on Technology in Education, 39, 2243. http://dx.doi.org/10.1080/15391523.2006.10782471

Busby, J. R., \& Mupinga, D. M. (2007). Requirements, Benefits, and Concerns of Technology Education Cooperating Teachers: An Exploratory Study among Nine Midwest Universities. The Journal of Technology Studies, 79-86. http://files.eric.ed.gov/fulltext/EJ847363.pdf http://dx.doi.org/10.21061/jots.v33i2.a.3

Choy, D., Wong, A. F. L., \& Gao, P. (2009-2010). Student Teachers' Intentions and Actions on Integrating Technology into Their Classrooms during Student Teaching: A Singapore Study. Journal of Research on Technology in Education, 42, 175-195. http://dx.doi.org/10.1080/15391523.2009.10782546 
Clarke, A., Triggs, V., \& Nielsen, W. (2014). Cooperating Teacher Participation in Teacher Education: A Review of the Literature. Review of Educational Research, 84, 163-202. http://dx.doi.org/10.3102/0034654313499618

Cornu, R. L., \& Ewing, R. (2008). Reconceptualising Professional Experiences in Pre-Service Teacher Education Reconstructing the Past to Embrace the Future. Teaching and Teacher Education, 27, 1799-1812.

http://dx.doi.org/10.1016/j.tate.2008.02.008

Creswell, J. W. (1998). Qualitative Inquiry and Research Design: Choosing among Five Traditions. Thousand Oaks, CA: Sage.

Creswell, J. W. (2013). Qualitative Inquiry \& Research Design: Choosing among Five Approaches (3rd ed.). Thousand Oaks, CA: SAGE.

Creswell, J. W., \& Plano Clark, V. L. (2011). Designing and Conducting Mixed Methods Research (2 ${ }^{\text {nd }}$ ed.). Thousand Oaks, CA: Sage.

Cuban, L., Kirkpatrick, H., \& Peck, C. (2001). High Access and Low Use of Technology in High School Classrooms: Explaining an Apparent Paradox. American Educational Research Journal, 38, 813-834.

http://dx.doi.org/10.3102/00028312038004813

Digital Transformation (2007) A Framework for ICT Literacy: A Report of the International ICT Literacy Panel. Educational Testing Services. https://www.ets.org/Media/Tests/Information_and_Communication_Technology_Literacy/ictreport.pdf

Dole, J. A. (2004). The Changing Role of the Reading Specialist in School Reform. The Reading Teacher, 57, 462-471. http://dx.doi.org/10.1598/RT.57.5.6

Duran, M., \& Fossum, P. R. (2010).Technology Integration into Teacher Preparation. Journal of Kirsehir Education Faculty, 11, 169-187.

Ertmer, P. A., \& Ottenbreit-Leftwich, A. T. (2010). Teacher Technology Change: How Knowledge, Confidence, Beliefs, and Culture Intersect. Journal on Research on Technology in Education, 42, 255-284. http://dx.doi.org/10.1080/15391523.2010.10782551

Grove, K., Strudler, N., \& O’Dell, S. (2004). Mentoring toward Technology Use: Cooperating Teacher Practice in Supporting Student Teachers. Journal of Research on Technology in Education, 37, 85-107. http://dx.doi.org/10.1080/15391523.2004.10782427

Guskey, T. R. (1995). Results-Oriented Professional Development: In Search of an Optimal Mix of Effective Practices. North Central Regional Educational Laboratory. http://www.ncrel.org/sdrs/areas/rpl_esys/pdlitrev.htm

Guskey, T. R. (2002). Professional Development and Teacher Change. Teachers and Teaching: Theory and Practice, 8, 381391. http://dx.doi.org/10.1080/135406002100000512

Guskey, T. R. (2003). What Makes Professional Development Effective? Phi Delta Kappan, 84, 748-750. http://dx.doi.org/10.1177/003172170308401007

Gutierrez, K. (2008). Developing a Sociocritical Literacy in the Third Space. Reading Research Quarterly, 43, 148-164. http://dx.doi.org/10.1598/RRQ.43.2.3

Hutchison, A. (2012). Literacy Teachers’ Perceptions of Professional Development That Increases Integration of Technology into Literacy Instruction. Technology, Pedagogy, and Education, 21, 37-56.

http://dx.doi.org/10.1080/1475939X.2012.659894

International Reading Association (2009). New literacies and Twenty-First Century Technologies: A Position Statement. http://www.reading.org

Joyce, B., \& Showers, B. (1988). Student Achievement through Staff Development. White Plains, NY: Longman.

Joyce, B., \& Showers, B. (2002). Student Achievement through Staff Development (3rd ed.). Alexandria, VA: ASCD.

Kelley, M., Gray, P. D., Reid, D. J., \& Craig, C. J. (2010). Within k-12 Schools for School Reform: What Does It Take? In N. Lyons (Ed.), Handbook of Reflection and Reflective Inquiry: Mapping a Way of Knowing for Professional Reflective Inquiry (pp. 273-298). USA: Springer Science + Business Media.

Koehler, M. J., \& Mishra, P. (2008). Introducing TPACK. In American Association of Colleges for Teacher Education Committee on Innovation and Technology (Ed.), Handbook of Technological Pedagogical Content Knowledge (TPACK) for Educators (pp. 3-29). New York: Routledge.

Lawless, K. A., \& Pellegrino, J. W. (2007). Professional Development in Integrating Technology into Teaching and Learning: Knowns, Unknowns, and Ways to Pursue Better Questions and Answers. Review of Educational Research, 77, 575-614. http://dx.doi.org/10.3102/0034654307309921

Leu Jr., D. J. (2010). Preparing Students for the 21st Century: How Can Teachers Incorporate New Literacies into Elementary Classrooms? Research into Practice: Pearson Scott Foresman. http://assets.pearsonglobalschools.com/asset_mgr/current/201135/mono_leu.pdf 
Leu Jr., D. J., Kinzer, C. K., Coiro, J. L., \& Cammack, D. W. (2004). Toward a Theory of Newliteracies Emerging from the Internet and Other Information and Communication Technologies. In R. B. Ruddell, \& N. J. Unrau, (Eds.), Theoretical Models and Processes of Reading (5th ed., pp. 1570-1613). Newark, NJ: International Reading Association.

Li, Q. (2007). Student and Teacher Views about Technology: A Tale of Two Cities? Journal of Research on Technology in Education, 39, 377-397. http://dx.doi.org/10.1080/15391523.2007.10782488

Lyons, C., \& Pinnell, G. S. (2001). Systems for Change in Literacy Education: A Guide to Professional Development. Portsmouth, NH: Heinemann.

Matsumura, L. C., Garnier, H., \& Resnick, L. B. (2010). Implementing Literacy Coaching: The Role of School Social Resources. Educational Evaluation and Policy Analysis, 32, 249-272. http://dx.doi.org/10.3102/0162373710363743

McKenzie, J. (1999). How Teachers Learn Technology Best? The Educational Technology Journal (Online), 11. http://fno.org/Oct01/coaching.html

Miles, M. B., \& Huberman, A. M. (1994). Qualitative Data Analysis: An Expanded Source Book. Thousand Oaks, CA: Sage Publications.

Mishra, P., \& Koehler, M. J. (2006). Technological Pedagogical Content Knowledge: A Framework for Teacher Knowledge. Teachers College Record, 108, 1017-1054. http://dx.doi.org/10.1111/j.1467-9620.2006.00684.x

Mouza, C. (2002). Learning to Teach with New Technology: Implications for Professional Development. Journal of Research on Technology in Education, 35, 271-289. http://dx.doi.org/10.1080/15391523.2002.10782386

Mumtaz, S. (2000). Factors Affecting Teachers' Use of Information and Communications Technology: A Review of the Literature. Journal of Information Technology forTeacher Education, 9, 319-341. http://dx.doi.org/10.1080/14759390000200096

National Council of Teachers of English (2008). Position Statement: Twenty-First Century Curriculum and Assessment Framework. http://www.ncte.org/positions/statements/21stcentframework

National Governors Association. (2010). Common Core State Standards for English Language Arts \& Literacy in History/Social Studies, Science, and Technical Subjects. Washington DC: National Governors Association Center for Best Practices, Council of Chief State School Officers. http://www.corestandards.org/

Palak, D., \& Walls, R. T. (2009). Teachers’ Beliefs and Technology Practices: A Mixed-Methods Approach. Journal of Research on Technology in Education, 41, 417-441. http://dx.doi.org/10.1080/15391523.2009.10782537

Partnership for $21^{\text {st }}$ Century Skills (2009). A Framework for Twenty-First Century Learning. http://www.p21.org/

Scot, T. P. (2004). Conditions, Processes and Consequences of Technology Integration: Policy to Practice. Unpublished Doctoral Dissertation. University of Virginia.

Shulman, L. (1987). Knowledge and Teaching: Foundations of the New Reform. Harvard Educational Review, 57, 1-23. http://dx.doi.org/10.17763/haer.57.1.j463w79r56455411

Stake, R. E. (1995). The Art of Case Study Research. Thousand Oaks, CA: SAGE.

Stake, R. E. (2000). Case Studies. In N. K. Denzin, \& Y. S. Lincoln (Eds.), Handbook of Qualitative Research (pp. 435-453). Thousand Oaks, CA: Sage.

Stolle, E. (2008). Teachers, Literacy and Technology: Tensions, Complexities, and Practices. In Y. Kim, V. J. Risko, D. L. Compton, D. K. Dickenson, M. K. Hundley, et al. (Eds.), 57th Yearbook of the National Reading Conference (pp. 56-69). Oak Creek, WI: National Reading Conference.

Taylor, B. M., Pearson, P., Peterson, D. S., \& Rodriguez, M. C. (2005). The CIERA School Change Framework: An Evidence-Based Approach to Professional Development and School Reading Improvement. Reading Research Quarterly, 40, 40-69. http://dx.doi.org/10.1598/RRQ.40.1.3

Vogt, B., \& Shearer, B. A. (2011). Reading Specialists and Literacy Coaches in the Real World. Boston, MA: Pearson.

Weiner, B. (2004). Cultural Plurality into Theoretical Unity. In D. M. McInerney, \& S. Van Etten (Eds.), Big Theories Revisited: Research on Sociocultural Influences on Motivation and Learning (Vol. 4, pp. 13-30). Greenwich, CT: Information Age Publishing.

Wright, V., \& Wilson, E. (2005). Social Studies Methods Course at the University of Alabama—Historical Field Trip. Contemporary Issues in Technology and Teacher Education, 5, 38-49.

Zeichner, K. (2010). Rethinking the Connections between Campus Courses and Field Experiences in College and University-Based Teacher Education. Journal of Teacher Education, 89, 89-99. http://dx.doi.org/10.1177/0022487109347671 


\section{Appendix A}

Individual Beginning Interview Protocol

1. Tell me about yourself as a teacher.

Follow up probes: What are your greatest strengths as a teacher?

What are your greatest areas of need as a teacher?

2. How do you believe students learn best?

3. How do you define new literacies?

4. What are your goals for technology integration?

5 . Tell me about your best experiences using technology in teaching?

6. Tell me about one meaningful way you had students use technology?

7. How could I best help you integrate technology in your classroom?

8. How do you envision working together (as student teacher/cooperating teacher) to integrate new literacies into your teaching?

9. What questions would you like answered regarding new literacies and technology integration?

\section{Appendix B}

Individual Exit Interview Protocol

1. What were the highlights of your semester together as student teacher/cooperating teacher?

2. Tell me about how you worked together to integrate new literacies into your teaching.

3. What role did each of you take in integrating technology?

4. Tell me about the role collaboration played in your new literacies integration.

Probe: How did coaching impact your new literacies integration? How did online peer sharing impact your new literacies integration?

5. What are some of the student technology projects you thought best exemplified your goals of new literacies integration.

6. How do you believe students learn best?

7. How do you define new literacies?

8. What goals do you have for integrating new literacies in your teaching next semester/year?

9. How did new literacies integration influence your student teacher/cooperating teacher collaboration?

10. What else would you like me to know about your experience as a student teacher/cooperating teacher team using technology?

\section{Appendix C}

Dyad Exit Interview Protocol

1. What was most helpful about having a partner as you integrate new literacies?

Probe: How can dyads best work together to use technology?

2. What did you do that you think helped students learn the most?

3. What technologies did you find to be most helpful in teaching?

4. What technologies do you think are the most helpful to use with students for student learning?

5. How do you think the added focus on technology influenced you as a student teacher/cooperating teacher dyad?

Probe: Did you see boundaries/leadership change at all?

6. What suggestion would you give to an incoming student teacher/cooperating teacher dyad to make their new literacies integration beneficial for teachers and students?

\section{Appendix D}

Observation Protocol

School Grade

Teacher Student Teacher

Date Observation number

Sketch of classroom: 
Subject observed:

Lesson plan objectives for the lesson (content \& technology):

New literacies skills taught:

Technology utilized:

Teacher Pedagogy:

Student use of new literacies:

Outline of lesson:

Purposes for technology integration:

(1) technology for technology's sake (2) replacement for traditional method (3) innovation

Quotes:

Unexpected findings:

Suggestions for further technology integration:

\section{Appendix E}

Student Teacher/Cooperating Teacher Online Technology Use Log

1. New literacies online skills include: identifying important questions, locating information, evaluating information, synthesizing information, and communicating findings (Leu, 2010).

Did you integrate new literacies in your teaching this week? (Yes No)

2. In how many lessons did you integrate technology in your teaching this week? (slide $0-15+$ )

3. How many hours did you integrate technology into your teaching this week? (slide $0-12+$ )

4. In which subjects did you integrate technology? (check all that apply)
Social Studies
Science
Reading
Writing
Math
Arts
Computer

5. Describe the best example of how YOU used technology in your TEACHING this week.

6. Describe the best example of how your STUDENTS used technology in LEARNING this week.

7. What apps, websites, or technologies did you use this week?

8. With whom did you collaborate: (check all that apply)

\begin{tabular}{|l|}
\hline Collaboration Partner \\
\hline another teacher in your school \\
\hline cooperating teacher/student teacher \\
\hline coach \\
\hline online community \\
\hline I did not collaborate with anyone \\
\hline
\end{tabular}

9. How did you collaborate?

10. How many hours did you spend learning technologies to prepare to teach lessons integrating technology? (slide 0 - 10+)

11. What goal do you set for new literacies integration in your subjects next week?

12. How could I best support you?

\section{Submit or recommend next manuscript to SCIRP and we will provide best service for you:}

Accepting pre-submission inquiries through Email, Facebook, Linkedin, Twitter, etc A wide selection of journals (inclusive of 9 subjects, more than 200 journals)

Providing a 24-hour high-quality service

User-friendly online submission system

Fair and swift peer-review system

Efficient typesetting and proofreading procedure

Display of the result of downloads and visits, as well as the number of cited articles

Maximum dissemination of your research work

Submit your manuscript at: http://papersubmission.scirp.org/ 